Olena Zelenko,

Doctor of Economics, Associated Professor, Volodymyr Dahl East Ukrainian National University, Central Ave. 59a, Severodonetsk, 93406, Ukraine

ORCID: 0000-0003-4880-246X

ResearcherID: V-9966-2017

\title{
TOURISM INDUSTRY AS THE BASIS FOR IMPRESSION ECONOMY
}

The presented materials highlight the peculiarities of the functioning for modern economic systems, which are developed on the basis of the provider's ability to create positive impressions for consumers. It is determined that the leading industry, which is capable to generate unique emotions throughout the whole cycle of creation and consumption of the finished product, is the tourism sphere. It is substantiated that tourism is the largest generator for a new type of economic capital - consumer impressions.The effective use of such capital contributes to the further economic development of entities insidetourism industry and regions in the country.

Keywords: tourism, impression economy, individual needs, uniqueness, efficiency.

Relevance of research topic. The intensive development of post-industrial society is accompanied by a total change in the essence of economic relations. Insteadof the mass production era, when consumers met their own needs through the purchase of standard goods and services, new conditions of management came. The market is oversaturated, and competition between similar manufacturers has moved to a new level. Competitive advantages under other equal conditions are obtained by those who are able to impress the potential client, evoke positive emotions and satisfaction from the consumption process.

The problem of finding a new path of development for the economic systems of many countries in the world and ensuring the sustainability of growth is relevant for today. Obsolescence of standard economy approaches, inefficiency of classic industries and agriculture have led to a reorientation of economic relations to a service sector, which from an additional one gradually turns into a leading branch of economic activity, because onlyhereit is possible formation of a unique product which is capable to influenceon the emotional component of the consumption process.

World practice shows thattourism is the most powerful industry which can deliver economic growth while meeting the individual needs of each consumer. It is an industry of service economics that creates impressions and promotes economic benefits based on them. 
Formulation of the problem. In Ukraine, against the backdrop of crises in standard sectors of the economy, tourism still remains a secondary sector of economic activity. Despite the world statistics, where the contribution of the tourism sector to GDP is over $10 \%$, the same indicator in Ukraine does not exceed $2 \%$. Therefore, substantiating the prospects of tourism development as a key factor in the success of the national impression economy is a timely and appropriate task for both scientists and practitioners of economic activity.

Analysis of recent researches and publications. Different aspects and development peculiarities of the impression economy were explored by both foreign and Ukrainian scientists. Among the domestic scientists we can mention the publications of Boiarska M. A. (Boyarskaya, 2016), Dyshkantiuk O. V. (Dyshkantiuk, 2016), Ushkarenko Yu. V., Chmut A. V., Syniakova K. M. (Ushkarenko, Chmut\&Syniakova, 2018), Chubukova O. Yu., Yarenko A. V. (Chubukova\&Yarenko, 2016), Yaromich S. A., Lakhtionova T. M., Popel' O. O. (Yaromich, Lakhtionova\&Popel', 2018) etc.

Most part of the available research addresses the general issues and features of the impression economy functioning, its theoretical aspects and conditions of implementation. At the same time, the role of the tourism industry in this sector of economic relations has been considered insufficiently, there is no sufficient justification for the tourism industry's involvement in the economy of impression and the feasibility of using this approach to further develop the tourism sphere itself.

Presenting main material. In the scientific environment, despite the fact that the phenomenon of impression economy has been studied since the end of the last century, there is still no single approach to its definition. Moreover, there is no single term. Some authors, in addition to the one already mentioned, use the suchterm as «exclusive economy», «creative economy». In some sources these concepts are synonymous, in other sources the economy of impression is considered as a component of the creative economy (Ushkarenko, Chmut\&Syniakova, 2018). In the general sense, the economy of impressions means the concept of economic systems development, where the main competitive advantage is creativity, which becomes a source of formation for new properties of goods and services, the use of which is accompanied by certain positive emotions. Such system of economic relations is focused not only on meeting standard needs, but on generating pleasant impressions that can occur during the production, promotion and consumption of an innovative product, which can leave positive feelings even after the consummation process (Boiarska, 2016). Economy of impressions is based on the psychological needs of each person to experience emotional uplift more often (Chubukova\&Yarenko, 2016) and those areas of economic activity that can create it, will be the most successful in the future.

The tourism industry is precisely the sphere of social activity which in its essence fully meets the criteria for the economy of impressions: 
- innovation in the context of globalization, which is achieved through the informatization of the industry;

- exclusivity, which is ensured by the individualization of the service process, as well as by the unique cultural and historical heritage, natural and recreational resources, national cultural model of behavior within an territory, or the country as a whole.

In the process of making a decision to purchase a tour, the consumer actually thinks about buying the appropriate impressions (Boiarska, 2016), which are an integral part of the tourist service process. The basis of the formation of impression economy within the tourism industry are considered such spheres of activity as:

1) the hotel industry, which provides the tourist with the impression of temporary accommodation (due to the exterior and interior of the hotel complex as well as the process of service);

2) restaurant business, which offers customers a unique experience of tasting gastronomic offerings and technology of serving customers during ordering, cooking and subsequent consumption of selected dishes;

3) entertainment industry, which offers the tourist unforgettable emotions connected with the organization of leisure while resting outside the place of residence;

4) excursion service companies offering new impressions of acquaintance with cultural and historical monuments and other well-known tourist attractions;

5) transport and transport infrastructure that provide the traveler with impressions of the comfort during the transfer from the place of residence to the place of rest (and vice versa), on a guided tour, etc.

The list of activities that form a complex tourist product, and therefore the initial, intermediate and final impressions of its consumption, we can continue for a long time (the sphere of finance that serves cash flows; social infrastructure of the tourist destination, etc.). Their effective interaction through the operation of established logistics chains (Dyshkantiuk, 2016) allows obtaining a synergistic effect: positive emotions that remain with the tourist during and after the trip, and then induce a similar purchase (new tour) in the future.

In the period of globalization, tourism, combining a large number of related industries, provides the creation of a so-called wow-service that does not leave indifferent and forms a further wow-effect (Yaromich, Lakhtionova\&Popel', 2018), which is manifested through customer loyalty to the providers of tourism services, reinviting them to take a new journey and relive the emotional uplift. As a result, generating unique impressions, tourism at the global level is developing more intensively than other areas of economic activity.

The success of the tourism industry is due to the implementation of the principle of «mass personalization» (Yaromich, Lakhtionova\&Popel', 2018), which provides full satisfaction of individual needs for each consumer, which guarantees a positive impression of a unique tourism product and economic effect for the industry in the form of real profit. 
Conclusion. At the present development stage of the economic relations system, the competitiveness of any industry is determined by its ability to generate and multiply a new kind of capital - positive consumer impressions. The tourism industry is precisely the sphere of economic activity that gives the opportunity to generate such capital and use it effectively both for the work of the tourist enterprises themselves and for the socio-economic development of the region. It creates an image of the territory in the eyes of potential tourists which will provide a unique impression.

Taking into account the arguments in favor of tourism, as a leading branch of the economy of impressions, it is advisable to refocus the vector of economic development of Ukraine and to pay attention to the tourism sphere, as the most promising type of economic activity and an alternative way of sustainable socioeconomic development of individual regions and the country as a whole.

\section{REFERENCE}

1. Boiarska, M. O. (2016). Thhhe essence and importance of the impression economy at the present stage of development of the Ukrainian economy. Young scientist. No. 4 (31), pp. 25-27.

2. Chubukova, O. Yu. \&Yarenko, A. V. (2016). Impressions economy: prerequisites of origin, main ideas, economic essence. KNUTD Bulletin. No. 6 (105), pp. 92-98.

3. Dyshkantiuk, O. V. (2016). Impressions economy is a modern stage of development of social production. Economics of the food industry. Volume 8. Issue 4. pp. 3-9.

4. Ushkarenko, Yu. V., Chmut, A. V. \&Syniakova, K. M. (2018). Creative economy: essence, concepts and significance for Ukraine in the conditions of European integration. Economy and society. 18, pp. 67-72.

5. Yaromich, S. A., Lakhtionova, T. M., Popel', O. O. (2018). Innovative aspects of impression's marketing in the field of tourism services. Market infrastructure. No. 21, pp. 203-207. 